\title{
Explorative and exploitative choices in response to initiative failure: Study of entrepreneurs and managers
}

\author{
Piotr Wójcik, Mariola Ciszewska-Mlinarič
}

A B S T R A C T

Objective: The objective of the article is to investigate how cognitive framing of initiative failure affects strategic decision-making by entrepreneurs and managers in terms of exploitation and exploration.

Research Design \& Methods: A set of hypotheses is tested in a quasi-experimental study using a scenario-based approach and a usable sample of 59 participants. Specifically, the data were analysed using two paired t-tests and a one-way multivariate analysis of variance (MANOVA).

Findings: We draw on prospect theory, behavioural theory, and the threat-rigidity hypothesis to investigate the individual intention to make explorative and exploitative choices in response to initiative failure. The study finds that - under the condition of uncertainty - the experience of initiative failure increases entrepreneurs' (decreases managers') willingness to make risky choices and decreases entrepreneurs' (increases managers') willingness to make risk-avoidant choices.

Implications \& Recommendations: This study differentiates the notion of initiative failure from the broader notion of entrepreneurial failure, showing that it has a stimulating (discouraging) effect on further entrepreneurial (managerial) intentions in terms of attitudes to risk. The study was conducted on a relatively small sample of participants representing businesses in Poland.

Contribution \& Value Added: This study extends existing lines of reasoning by considering initiative failure - clearly delineating it from entrepreneurial failure - and testing its effect on intentions to make strategic choices among entrepreneurs and managers. Decision-makers' responses cannot be explained solely by the behavioural theory and individual factors, as they are also affected by the organisational context.

Article type: research article

Keywords: failure; decision-making; entrepreneurship, behavioural theory JEL codes: $\quad$ D70, L26, M13

Received: 4 January $2020 \quad$ Revised: 11 June $2020 \quad$ Accepted: 13 June 2020

\section{Suggested citation:}

Wójcik, P., \& Ciszewska-Mlinarič, M. (2020). Explorative and exploitative choices in response to initiative failure: Study of entrepreneurs and managers. Entrepreneurial Business and Economics Review, 8(3), 83-99. https://doi.org/10.15678/EBER.2020.080305 


\section{INTRODUCTION}

The topic of perception of and responses to failure has attracted considerable attention in the field of entrepreneurship (Ucbasaran, Westhead, Wright, \& Flores, 2013). This is not surprising given that entrepreneurship is a risk-involving activity that leads to failure more often than not (McGrath, 1999). However, most of the research in this area focuses on successes, while limited attention has been paid to failures (Yamakawa, Peng, \& Deeds, 2015). This is thought-provoking, since failures may have salient impacts on entrepreneurs' future choices.

Entrepreneurial failure refers to the termination of an entrepreneurial venture (e.g., Shepherd, Wiklund, \& Haynie, 2009; Yamakawa, Peng, \& Deeds, 2015) or ownership discontinuance (Shepherd, 2003) due to the fall of performance below a critical threshold level, which leads to insolvency or bankruptcy and is often referred to as business failure.

Scholars characterise entrepreneurial failure in terms of causes and consequences for entrepreneurs and the entrepreneurial process (Khelil, 2016). Business failure experience is believed to impact risk attitudes and further choices with appropriate influence on entrepreneurs' perception of risk (Al Mamun, \& Ibrahim, 2019; Kozubíková, Dvorský, Cepel, \& Balcerzak, 2017). On the one hand, the perception of risk is considered a source of knowledge and learning that contribute to the enhancement of social capital, which in turn is used in further re-entry (Shepherd, 2003; Ucbasaran et al., 2013). On the other hand, failures that are too intense, too numerous or too frequent may have detrimental effects on further entrepreneurial action (Fang He, Sirén, Singh, Solomon, \& von Krogh, 2018).

However, while studies in entrepreneurship contribute to the understanding of how business failure affects emotions, entrepreneurial learning, and action, they remain silent in regard to the role of initiative failure in the same respect. Acknowledging single initiatives in entrepreneurship research is important because of their cumulative influence on a firm's overall performance and, thus, its survival and growth. The entrepreneurial process involves testing different assumptions around which a number of initiatives are organised. The execution of these initiatives can lead to a continuum of outcomes, ranging from below to above the aspiration level, thus affecting decision-makers' related action. As opposed to business failure, initiative failures provide frequent and continuous feedback, incrementally enhancing the knowledge base and, hence, they play a vital role in shaping the entrepreneurial process. Support for the assertion that past experience affects future intentions and behaviour can be found in both the theory of entrepreneurial learning (e.g. Cope, 2011) and the theory of planned behaviour (Ajzen, 1991). Therefore, the analytical level of a particular initiative offers an opportunity to trace cause-effect relationships in a more precise way than business failure at the aggregated level of the entire company, as the ultimate outcome of a business venture may also be affected by external incidental or discontinuous/radical events. At the heart of this issue lies the question of whether - after experiencing an initiative failure - entrepreneurs are more willing to adapt with a flexible response and engage in a significant change in their strategy or would they rather "play it safe" by applying existing solutions, business models, and products? Studies in entrepreneurship and strategy emphasise the importance of cognitive bias and framing effects in this respect (e.g., Simon \& Schrader, 2012). However, the existing entrepreneurship research and decision-making theories remain equivocal 
on how initiative failure could potentially impact responses. Moreover, the literature suggests that individual traits (e.g. Dew, Read, Sarasvathy, \& Wiltbank, 2008) and organisational context (Cyert \& March, 1963; Ocasio, 1997) affect the level of risk aversion involved in the decision-making process after a decision-maker faces a form of failure. Taken together, the extant studies overlook the relationships between initiative failure, entrepreneurial cognition, and behaviour.

We address this gap by asking: How does cognitive framing of initiative failure affect further strategic decision-making by entrepreneurs and managers in terms of exploitation and exploration? Furthermore, we aim to identify how entrepreneurs and managers differ in their responses to initiative failure.

We conducted a quasi-experimental study with a scenario-based approach, using a cover story followed by a questionnaire and inviting participants to a computer lab. Our purpose was to identify the effect of initiative failure on subsequent intentions to make two strategic choices - exploration and exploitation - which respectively correspond to risk-seeking and risk-averse behaviour. In order to understand the specificity of entrepreneurs' responses, we compare them with managers' responses under the same conditions.

This study makes three contributions to the entrepreneurial failure literature. Firstly, while the majority of studies focus on failure on the aggregate organisational level, they overlook the level of individual initiatives. Our study fills this gap.

Secondly, the entrepreneurship research underlines the importance of entrepreneurs' cognition in the entrepreneurial process (Shepherd, Williams, \& Patzelt, 2015). However, the role of cognitive framing of and response to initiative failure in terms of intentions remains unclear. Hence, this study draws from entrepreneurship, behavioural strategy research, and decision-making theories to identify whether and how cognitive bias may affect further strategic choices in response to initiative failure.

Third, entrepreneurial failure research focuses on developed economies, leaving transition economies, especially those of Central and Eastern European (CEE) countries, relatively unaddressed. In this respect, the applicability of entrepreneurship research findings from developed economies to the context of transition economies is questionable (Bruton, Ahlstrom, \& Obloj, 2008). Therefore, this study contributes by considering entrepreneurs' and managers' responses to initiative failure by bringing to the fore the empirical setting of Poland.

The remainder of the paper is organised as follows. Firstly, we review the literature on uncertainty as the context for decision-making and explain the relationship between framing effect and decision-making in response to initiative failure. We then develop hypotheses. Next, we present basic information about our sample and justify the use of the experimental method. Further, we test hypotheses by employing paired t-test and one-way MANOVA methods, followed by a discussion of the study results and contributions. We conclude by discussing limitations of the study and presenting avenues for future research.

\section{LITERATURE REVIEW}

\section{Uncertainty and Entrepreneurial Choices}

Entrepreneurship and uncertainty are inseparable (Kirzner, 1973). Uncertainty stems from an inability to assign probabilities to future events due to a lack of information about cause-effect relationships and a decision's outcome (Hoskisson \& Busenitz, 2002; Aulová, 
Pánková, \& Rumánková, 2019). Some authors consider entrepreneurs as particularly capable of dealing with uncertainty, as their cognitive abilities allow them to effectively identify market opportunities or apply new methods of resource usage (Simon \& Schrader, 2012; Křečková \& Brožová, 2017; Ključnikov, Civelek, Čech, \& Kloudová, 2019). However, sole focus on seeking new opportunities, instead of exploiting existing ones, may be myopic and detrimental on long-term firm performance. Therefore, the appropriate allocation of limited resources between two strategic approaches - seeking new (exploration) and exploiting existing opportunities (exploitation) - plays a major role in new venture's survival and growth (Hitt, Ireland, Sirmon, \& Trahms, 2011). Exploitation focuses on the incremental improvement and re-use of existing routines (March, 1991). Exploration focuses on discontinuous changes, experimentation, risk taking, and innovation (March, 1991). As March (1991) argues, "both exploration and exploitation are essential for organisations, but they compete for scarce resources" (p. 71), because they require different structures, capabilities, and processes. As Ireland, Hitt, and Sirmon (2003) put it, the balance between "both opportunity-seeking and advantage-seeking behaviours are necessary for wealth creation, yet neither alone is sufficient" (p. 965). Therefore, exploitation could be argued to align with risk-averse choices, whereas exploration would be aligned with risk-seeking choices.

\section{Initiative Failure}

The consequence of choices made under conditions of uncertainty is that entrepreneurs more often face a form of failure rather than the expected success (McGrath, 1999; Hudáková \& Dvorský, 2018). The literature mostly interprets entrepreneurial failure in terms of business termination due to not meeting goals (Shepherd, 2003; Shepherd et al., 2009). This article considers a more nuanced view and recognises failure regarding an entrepreneurial initiative. Initiative failure is defined as the termination of an organisational value-creating initiative that has fallen short of its goals (McGrath, 1999; Shepherd et al., 2011). Initiatives have a very close meaning to projects - understood as "new venture, new product, new service, entering new markets, and/or implementing new processes" (Shepherd \& Cardon, 2009, p. 923) - but they lack the structure and discipline typical for project management; i.e., an initiative does not necessarily have assigned roles or key performance indicators. Repetition of these failures and their cumulation over time may lead to the venture's termination in the long term but each one separately unlikely result in immediate bankruptcy (Yamakawa et al., 2015). Due to low performance - i.e. below targets defined by the initiative's key resource provider (Shepherd et al., 2009) - initiative failure can be considered as a driver of new emotions and related actions (behaviour) in decision-makers (Shepherd \& Cardon, 2009). However, initiative failure triggers a different form of learning and affects further decision-maker's choices differently as compared to business failure. This mechanism stems from the fact that the former type induces shallower financial and emotional losses. For these reasons, in contrast to business failure, initiative failure is more likely associated with "failure tolerance" among leaders. Therefore, it becomes easier for an individual to reframe the initiative failure as an opportunity to learn and regain losses by engaging in a new initiative (see Shepherd et al., 2011). 


\section{Framing Effect and Decision-Making}

Because failure deviates from expected outcome, being "somehow surprising or confusing" (Maitlis, 2005, p. 21), it is subject to interpretation and undergoes the mental process of sensemaking. Due to uncertainty and decision-makers' personal goals, beliefs, and values, the decision-making process involves the phenomenon of cognitive bias. Preferences towards risk are the product of an individual's values, have been conceptualised under the notion of "framing effect," and are argued to depend on context; i.e. individuals are risk-averse in the domain of gains and risk-seeking in the domain of losses (Kahnemann \& Tversky, 1982).

Risk connotes decisions made under the condition of outcome certainty. However, because decision-makers in real management situations operate in the space of uncertainty rather than risk (Schoemaker, 1990), one needs to make an assumption to be able to apply such a logic to the management context. Decision-makers are convinced that they can control the future to some extent (March \& Shapira, 1987) when choosing from among alternative actions. To that end, they are faced with a dilemma of choosing between alternatives that will either lead to a probable success (i.e., meeting or exceeding the goal) or failure (i.e., not meeting the initiative's ultimate goal). In this sense, decisions are made depending on the individual belief that one scenario is more probable than another one to bring desired outcomes. Consequently, intentions and ensuing decisions can be traced to two alternative scenarios respectively corresponding to riskseeking and risk-averse choices in a given context; i.e., when a decision-maker believes that the preferable outcome is more or less probable.

\section{Hypotheses Development}

Entrepreneurial failure is a complex social phenomenon affecting cognition and emotions. Researchers find that business failure presents opportunities for sensemaking, learning (Ucabasaran et al., 2013; Yamakawa et al., 2015), and developing new business skills (Espinoza-Benavides \& Díaz, 2019). However, learning is not automatic, because failures induce negative emotions such as grief, which reduces individuals' ability to process information in the short term (Shepherd, Patzelt, Williams, \& Warnecke, 2014) and, thus, may have a demotivational effect leading to a decrease of self-confidence and risk-taking propensity of entrepreneurs (e.g., Shepherd, 2003). As a result, changes in the nature of strategic choices in the case of future market re-entry are unlikely to occur. Otherwise, business failure ultimately enables the exploitation of new entrepreneurial opportunities through entrepreneurs' alertness - i.e. the cognitive capability to recognise and exploit new business ideas (Bilan, Mishchuk, \& Pylypchuk, 2017; Boso, Adeleye, Donbesuur, \& Gyensare, 2019) - and to enhance firm innovativeness through reflection and constructive conflict (Danneels \& Vestal, 2020). A recent study by Kauppinen, Paloniemi, and Juho (2019) shows that when learning is supported by mentors, after failing in their businesses, start-up founders are more likely to try again. In a study of Chinese serial entrepreneurs, Lin, Yamakawa, and Li (2019) found that failure experiences are positively associated with substantial strategic changes in subsequent entrepreneurship endeavours. Likewise, Acheampong and Tweneboah-Koduah (2018), in their study of Ghanian entrepreneurs, 
found that past entrepreneurial failure has a positive effect on future entrepreneurial intentions, promoting their explorative learning behaviour. So far, conceptual and empirical studies have considered business failure rather than initiative failure (see McGrath, 1999). For this reason, they seem not to precisely match our issue of interest, i.e. initiative failure. However, empirical studies in the behavioural tradition have provided some indirect arguments allowing us to consider decision-makers' reaction to initiative failure. Namely, the literature shows that decision-makers are more willing to accept risk in problematic situations (e.g., Greve, 2003; Kahneman \& Tversky, 1982). Specifically, the above suggests that initiative failure will likely lead to a change in perception of the future situation. Kahneman and Tversky (1979, p. 286-287) overtly assume that entrepreneurs after a loss are "likely to accept gambles that would be unacceptable otherwise." Therefore, the framing effect within prospect theory will likely be applicable in the case of entrepreneurs:

H1a: Entrepreneurs' intention to make explorative choices is significantly higher after experiencing initiative failure than before experiencing it.

H1b: Entrepreneurs' intention to make exploitative choices is significantly lower after experiencing initiative failure than before experiencing it.

The prior research suggests that particular responses to business failure may differ between entrepreneurs and managers.

Firstly, studies in entrepreneurship attribute different responses to personal traits of entrepreneurs and non-entrepreneurs. Entrepreneurs were found to exhibit a higher propensity toward risk than managers (Stewart \& Roth, 2001) and exhibit greater optimistic overconfidence (Simon \& Shrader, 2012) than non-entrepreneurs. In this regard, a supporting view is offered by the research on decision-making logic among entrepreneurs and managers, who present two distinct approaches: effectuation and causation (Sarasvathy, 2001). In effectual logic, the entrepreneur develops an opportunity in short-term experiments and pivots when new information is available. Effectuation assumes that the entrepreneurial process relies on leveraging environmental contingencies by employing flexible choices (Benazzouz, 2019). Causation assumes that any business undertaking requires creating a clear plan of action aiming to achieve the defined final objective up front (Hauser, Eggers, \& Güldenberg, 2019). This approach focuses on selecting between means to maximise expected returns (Sarasvathy, 2001). The application of particular decision-making logic depends on two main factors. First is the stage in a company's lifecycle. Decisionmakers shift their decision-making from effectual in the early stage to causal when the firm grows and matures (e.g. Ciszewska-Mlinaric, Obloj, \& Wasowska, 2016).

The effectual logic relies on constant experimentation. Entrepreneurs will likely use effectuation and, hence, flexibly react to changing circumstances by adjusting goals to available means. In this way, they will be less concerned with future threats (Read, Sarasvathy, Dew, \& Wiltbank, 2016). Flexibility contributes to exploratory learning and choices by identifying, understanding, and applying new knowledge in response to rapidly changing environments (Cai, Guo, Fei, \& Liu, 2017). Causation logic predicts that - in the case of adverse experience or low performance - managers adapt via defined rules related to avoiding uncertainty, revealing a tendency to maintain existing procedures. Actual outcomes falling below desired goals in the short term stimulate the search for existing and known solutions to the problem (i.e. exploitative choices; Cyert \& March, 1963). In this 
regard, Zahra (1996) shows that managers are less willing to make risky choices in times of performance downturn than in times of prosperity.

Secondly, the potential source of difference in choices of response to failure is associated with the decision-making context, which leads to the development of different cognitive schemata. Greater uncertainty favours effectuation, while risk-related situations favour causation (Vershinina, Barrett, \& McHardy, 2017). Managers focus on different types of issues in their work than do firm owners. This resonates with the attention-based view of the firm, which suggests that organisations create the context for decision-making by imposing appropriate structures that "allocate and distribute the stimuli that channel the attention" (Ocasio, 1997, pp. 187-188).

Therefore, entrepreneurship and strategy research suggest that in the context of initiative failure, entrepreneurs will more likely make explorative choices and less likely make exploitative choices compared to managers.

H2a: After experiencing an initiative failure, entrepreneurs demonstrate significantly higher intention to make explorative choices than managers.

H2b: After experiencing an initiative failure, entrepreneurs demonstrate significantly lower intention to make exploitative choices than managers.

\section{MATERIAL AND METHODS}

\section{Participants}

Participants included 40 practicing entrepreneurs and 36 managers. Participation in this study was on a voluntary basis. Recruited through two entrepreneurship associations, the entrepreneurs were founders actively running their businesses in the information technology (IT) industry and had one to ten years of experience in establishing and running a business (Mean $=4.38$ ). The managers were recruited through a university MBA program for middle-level decision-makers in the IT industry. The experience in decision-making in sales and marketing ranged from three to seven years (Mean $=5.08$ ). We ensured that the recruited managers did not have any entrepreneurial experience or intention by controlling for entrepreneurial intention (Liñán \& Chen, 2009). We checked for prior entrepreneurial experience in direct questions. Participants who reported a high level of entrepreneurial intention (i.e., mean score above 3.5 on a seven-point Likert scale) or with previous experience as entrepreneurs were excluded from further analyses. In total, 76 questionnaires were completed and returned. We excluded answers indicating careless responses based on unusually short measure time (i.e. less than the mean minus the standard deviation, as measured in the survey software tool; cf. Meade \& Craig, 2012). The ultimate usable sizes of research groups were, respectively, 34 entrepreneurs and 25 managers. The respondents' demographic data are summarised in Table 1.

The study context is Poland, which has undergone the process of transformation from a centrally planned to a market economy. However, this market development has come with challenges of transformation. Despite remarkable economic development in the past 30 years, both aspiring and experienced entrepreneurs have faced many difficulties due to underdeveloped country institutions, reflected in poor access to financing (Czemiel-Grzybowska \& Skowronek-Mielczarek, 2017), weak institutional support, insufficient innovation capacity, resource constraints, and legal and political instability 
(Gorączkowska, 2018; Lewandowska \& Stopa, 2018; 2019). Furthermore, these conditions expose entrepreneurs to higher environmental uncertainty compared to their peers from developed markets (e.g., Covin \& Miller, 2014). These institutional conditions offer a unique opportunity to extend prior research and help to understand the context of entrepreneurs' decision-making. In such an unfavourable and quickly changing external environment, the entrepreneurial process has for a long time involved a relatively large number of challenges vis-à-vis developed economies.

Table 1. Respondents' demographic data

\begin{tabular}{|l|c|c|c|c|c|}
\hline $\begin{array}{c}\text { Respondent } \\
\text { category }\end{array}$ & $\mathbf{N}$ & Age (years) & Gender & $\begin{array}{c}\text { Total experience in cur- } \\
\text { rent position (years) }\end{array}$ & $\begin{array}{c}\text { Total experience in } \\
\text { IT industry (years) }\end{array}$ \\
\hline Entrepreneurs & 34 & $\begin{array}{c}25-41 \\
\text { Mean }=29.2\end{array}$ & $\begin{array}{c}\text { Male }=18 \\
\text { Female }=16\end{array}$ & $\begin{array}{c}\text { Mean }=4.38 \\
\text { Dominant }=4\end{array}$ & Mean = 5.14 \\
\hline Managers & 25 & $\begin{array}{c}32-47 \\
\text { Mean }=37.3\end{array}$ & $\begin{array}{c}\text { Male }=12 \\
\text { Female }=13\end{array}$ & $\begin{array}{c}\text { Mean }=5.08 \\
\text { Dominant }=4\end{array}$ & Mean = 9.21 \\
\hline
\end{tabular}

Source: own study.

\section{Materials and Procedure}

To address our research questions, we employed a quasi-experimental design. This method has been extensively used in different management disciplines and is now gaining popularity in entrepreneurship studies (Hsu, Simmons, \& Wieland, 2017b). The experimental design assumes the application of a laboratory setting, thus a simplification of reality: "The goal of experiments is to examine causality (internal validity) rather than to generalise results to other situations or populations (e.g., external validity)" (p. 399). Our study considers one particular initiative and its failure: an event that we create artificially. In doing so, we can extract the 'pure' effect of initiative failure on further choices for analytical purposes. Hence, we believe that our research design provides a reliable test of our research question. In contrast to correlational design, experimental design allows us to address theoretical questions but requires caution when applying the findings in a business setting.

Our experimental study took the form of a questionnaire using scenarios, conducted via a popular online survey tool. Participants were invited to participate anonymously in the study in a computer lab and could not communicate among themselves. They were asked to fill in a questionnaire consisting of three parts. The first part included questions related to gender, entrepreneurial and professional experience, and entrepreneurial intention.

In the second part, respondents read a short cover story asking them to imagine themselves in the position of a CEO of a young technological venture operating in the audiobook industry. It presented an imaginary market situation with the aim of evoking a high sense of market uncertainty. To create an artificially high level of uncertainty, we used a description of the industry's characteristics (competitors, distribution channels, etc.) and provided limited information about the causes of arising rivalry. Respondents were then asked about the strategy they believed to be appropriate to follow and were presented with statements referring to exploration and exploitation constructs. We operationalised initiative failure in the third part. We elicited the sense of failure among respondents by showing a message on a screen stating that a computer algorithm had analysed their answers and concluded that their decisions would most likely lead to significant losses and subsequent bankruptcy in the next 18 months. Participants were also informed that there was a chance to rebuild their 
firm's market position. The message on the computer screen asked them to make another set of decisions based on both exploration and exploitation measures simultaneously.

The categories of the independent variable were formed by two groups of participants (entrepreneurs and managers). This was done for the purpose of the analysis regarding hypothesis 2. Dependent variables (i.e., exploration and exploitation) were measured using He and Wong's (2004) four-item scales. All survey items used a five-point Likert scale. We enhanced the validity of the construct measures with a pre-test and adapted them to the audiobook industry. For exploration measure, participants were asked to indicate the extent to which they agree with each of the following statements: (1) introduce new products (e.g., headphones, personal audio players); (2) extend product range (e.g., newspapers, poems, weekly magazines); (3) enter new markets (addressing new customer segments, foreign expansion); (4) enter new technology fields (development of software for fast text-to-voice translation). For exploitation measure, the following statements were used: (1) improve existing product quality; (2) improve existing sales and marketing; (3) reduce audiobook production cost (e.g., reduce the number of "superproductions" with celebrities); (4) improve the number of produced audiobooks or reduce operational costs.

To determine the internal consistency of multi-item scales, we examined Cronbach's alphas. The results showed acceptable values, which allowed us to combine the scores into mean values for both dependent variables (Nunnally, 1978). In all cases, Cronbach's alphas were greater than 0.6 and varied between 0.607 and 0.915 ; thus, they satisfied Nunnally's threshold level of acceptable reliability (Álamo-Vera \& Suárez-Ortega, 2005).

\section{RESULTS AND DISCUSSION}

Statistical analysis was conducted using the SPSS software. Table 2 presents the descriptive statistics.

Table 2. Descriptive statistics

\begin{tabular}{|l|l|c|c|c|c|c|}
\hline \multirow{2}{*}{ Variable } & \multirow{2}{*}{ Respondent Category } & \multirow{2}{*}{$\mathbf{N}$} & \multicolumn{2}{c|}{ Before failure } & \multicolumn{2}{c|}{ After failure } \\
\cline { 4 - 8 } & & & Mean & SD & Mean & SD \\
\hline \multirow{2}{*}{ Exploitative choices } & Entrepreneurs & 34 & 3.63 & 0.65 & 2.56 & 0.83 \\
\cline { 2 - 8 } & Managers & 25 & 3.39 & 0.79 & 3.46 & 0.76 \\
\hline \multirow{2}{*}{ Explorative choices } & Entrepreneurs & 34 & 3.35 & 0.71 & 4.03 & 0.42 \\
\cline { 2 - 7 } & Managers & 25 & 3.66 & 0.65 & 3.28 & 0.75 \\
\hline
\end{tabular}

Source: own study.

Dependent variables' scores were normally distributed for each research group, as assessed by the Shapiro-Wilk test ( $p \geq 0.05$ ), whose results are presented in Table 3 .

Before the hypotheses were tested, we checked for differences between answers of the two studied groups as a response to the scenario before they were shown a failure message. To do this, we used the one-way multivariate analyses of variance (MANOVA). The differences were not statistically significant at $F(4,176)=1.65, p=$ 0.160, Wilk's $\lambda=0.923, \eta_{\rho}^{2}=0.036$. 
Table 3. Shapiro-Wilk's normality tests

\begin{tabular}{|l|l|c|c|c|}
\hline \multicolumn{1}{|c|}{ Variable } & Respondent category & Statistics & Df & Sig. \\
\hline \multirow{2}{*}{ Exploitation } & Entrepreneurs & 0.951 & 34 & 0.131 \\
\cline { 2 - 5 } & Managers & 0.960 & 25 & 0.422 \\
\hline \multirow{2}{*}{ Exploration } & Entrepreneurs & 0.954 & 34 & 0.162 \\
\cline { 2 - 5 } & Managers & 0.947 & 25 & 0.265 \\
\hline \multirow{2}{*}{$\begin{array}{l}\text { Exploitation } \\
\text { (follow-up test) }\end{array}$} & Entrepreneurs & 0.938 & 34 & 0.053 \\
\cline { 2 - 5 } $\begin{array}{l}\text { Exploration } \\
\text { (follow-up test) }\end{array}$ & Managers & 0.919 & 25 & 0.050 \\
\hline
\end{tabular}

Source: own study.

To test hypothesis 1, a paired t-test was conducted for entrepreneurs (Table 4, Figure 1). The results showed that entrepreneurs revealed significantly lower exploitation scores after receiving the failure message $(t(33)=-7.20, p<0.001)$. In turn, the experimental factor showed a significant increase of 0.676 in exploration scores, $t(33)=5.94, p<0.001\left(M_{\text {before }}=3.350, S D=0.710 ; M_{\text {after }}=4.029, S D=0.421\right)$. Therefore, hypotheses $1 \mathrm{a}$ and $1 \mathrm{~b}$ are supported.

Table 4. Paired sample t-tests (entrepreneurs)

\begin{tabular}{|l|l|c|c|c|c|c|c|}
\hline \multicolumn{2}{|c|}{ Variable } & Mean & SD & Std. Error Mean & t & df & Sig. (2-tailed) \\
\hline Pair 1 & Exploitative choices & -1.073 & 0.869 & 0.149 & -7.200 & 33 & 0.000 \\
\hline Pair 2 & Explorative choices & 0.676 & 0.664 & 0.114 & 5.937 & 33 & 0.000 \\
\hline
\end{tabular}

Source: own study.

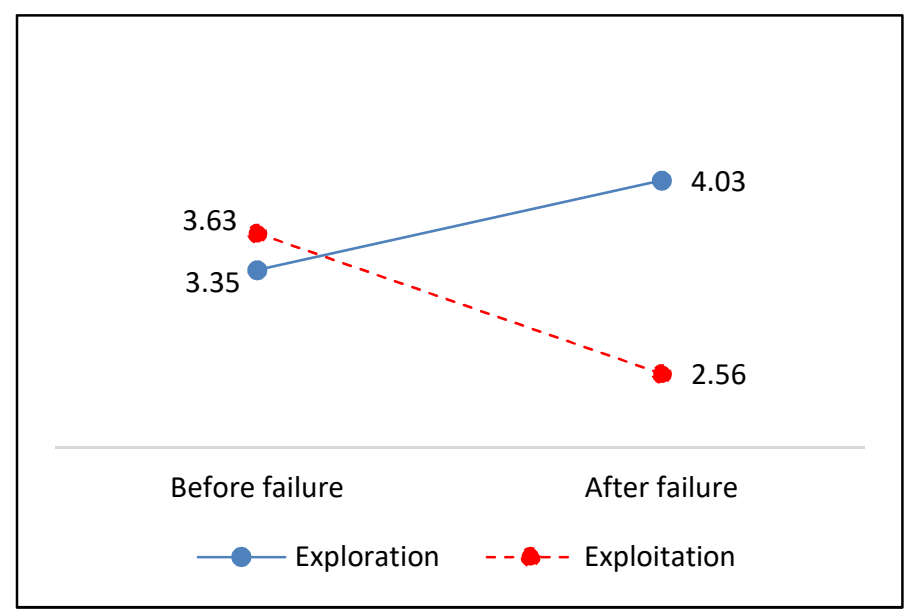

Figure 1. The effect of failure on strategic choices among entrepreneurs Source: own elaboration. 


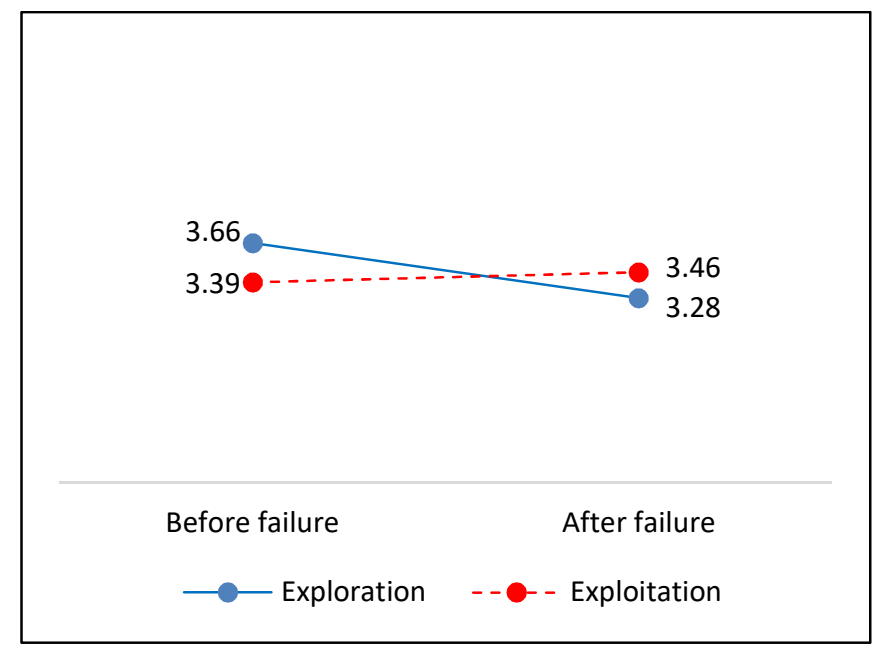

Figure 2. The effect of failure on strategic choices among managers Source: own elaboration.

Hypothesis 2 was tested using the one-way MANOVA. There appeared homogeneity among variance-covariances matrices, as assessed by Box's test of the equality of covariance matrices $(M=10.240, p=0.020)$. There was the homogeneity of variances, as assessed by Levene's test $(p>0.05)$. There also appeared a statistically significant difference between the decision-makers' types on the combined dependent variables, $F(2,56)=28.993, p<$ 0.001 , Wilk's $\lambda=0.491, \eta_{\rho}^{2}=0.509$. Entrepreneurs showed significantly higher mean exploration scores than managers. For exploitation, entrepreneurs revealed significantly lower scores than did managers (Figure 3 ). These results support hypothesis $2 \mathrm{a}$ and hypothesis $2 \mathrm{~b}$.

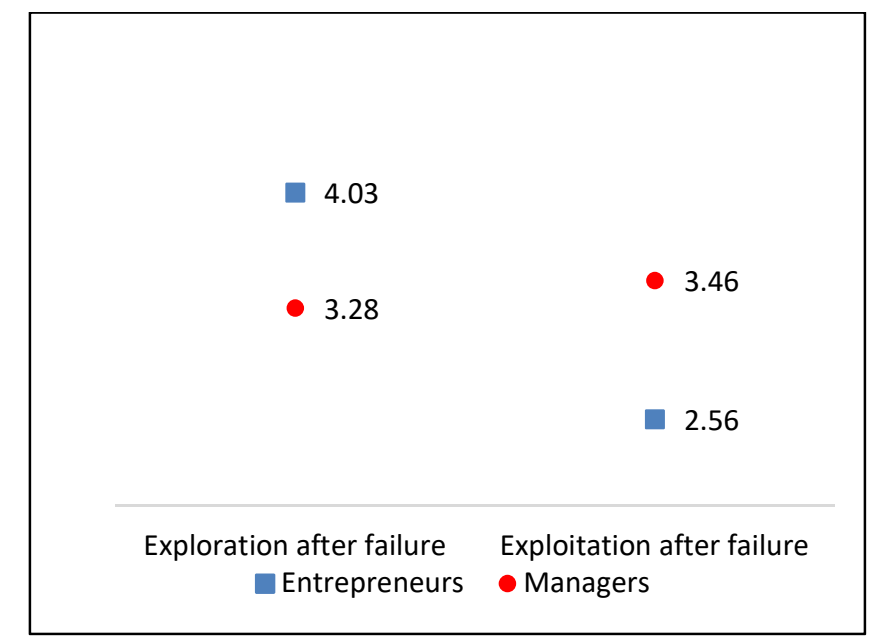

Figure 3. The effect of failure on strategic choices between entrepreneurs and managers Source: own elaboration. 
Prior work focuses on the relationships between business failure, learning from such failure (Cope, 2011; Fang He et al., 2018), and emotions as moderators of this relationship (Fang He et al., 2018; Hsu et al., 2017a; Shepherd et al., 2009). This paper revisits and extends prior research by addressing the issue of cognitive framing of initiative failure and its impact on further strategic choices in the context of the transition economy of Poland. The results of this study provide an empirical test of three hypotheses, and the results support hypotheses $\mathrm{H} 1$ and $\mathrm{H} 3$. Ultimately, our findings present implications for extant theoretical and empirical studies.

Firstly, prior research on entrepreneurial failure focuses on the aggregate level of the company (i.e. business failure). In this study, we apply a lower-level theoretical lens to distinguish initiative failure; a notion conceptually close to that of project failure. Following Shepherd et al. (2011), we argue that initiative failure is more common than business failure, and its cumulative effect on ultimate business failure is significant; nonetheless, research to date has remained silent about it. Interestingly, the results of this study are in line with the suggestion of prior studies on business failure in that initiative failure increases (decreases) the intention to make explorative (exploitative) choices (Acheampong \& Tweneboah-Koduah, 2018; Cardon et al., 2005; Hayward et al., 2006; Lin et al., 2019). In this respect, we suggest that - in new ventures - initiatives serve as vehicles for testing assumptions that incrementally provide continuous feedback and enhance the knowledge base. In this sense, they affect future choices. These results seem to confirm the assumption that entrepreneurs exhibit a "positive" bias and demonstrate greater optimism and self-confidence (Simon \& Shrader, 2012), which makes them more risk-prone on a systemic basis relative to managers (Stewart \& Roth, 2001).

Secondly, this study shows that initiative failure is subject to interpretation and stimulates decision-makers to a behavioural response. Similarly to a business failure, initiative failure affects future behavioural intentions. Considering individual and organisational factors, we were able to offer new insights into the antecedents of individual risk-related choices. We found that response to the initiative failure (in terms of bias from expected performance) led to flexible behaviour. Contrary to what psychology and organisational decision-making theories suggest - but in line with effectuation theory (Acheampong \& Tweneboah-Koduah, 2018; Lin et al., 2019) - the entrepreneurs we studied displayed an increased tendency towards risk-seeking behaviour (i.e. intention to make explorative choices) in response to initiative failure. Moreover, this effect was stronger than the one observed among managers. This finding seems to converge with Sarasvathy, Simon, and Lave's (1998) results. They found that entrepreneurs control the outcomes at a given risk level and frame problems in accordance to their personal values. In turn, managers tend to control the risk within structured problem spaces and avoid situations in which they risk high levels of personal responsibility.

This suggests that prospect theory (Kahneman \& Tversky, 1979) well explains entrepreneurs' behaviour after experiencing initiative failure. The opposite explanation holds for managers. Therefore, our results tend to support escalation bias (McCarthy et al., 1993) in the case of entrepreneurs. In sum, our findings call into question the assumption that failure induces demotivation, trauma, grief, and debilitation (e.g., Cope, 2011; Shepherd, 2003). Our findings may be attributable to the fact that our focus of interest is initiative failure, which causes a relatively low level of negative emotions, as opposed 
to business failure. This may suggest that small failures play a motivating role for entrepreneurs, inclining them to other experiments.

Thirdly, although there is significant research in developed economies (e.g., Fang He et al., 2018; Hsu et al., 2017a; Yamakawa et al., 2015) and a growing body of literature in emerging and transitional economies (e.g., Acheampong \& Tweneboah-Koduah, 2018) on entrepreneurial failure, very few scholars examined how initiative failure affects future choices in transitional economies. Relying on data obtained from Poland, our results indicate that initiative failure positively influences explorative decision-making and that this effect is stronger for entrepreneurs than managers. Our findings contribute to research on entrepreneurial failure by extending the application of prospect theory and effectuation in transitional economies in the context of initiative failure. These results remain consistent with prior findings in that effectuation logic is a more effective strategy in new ventures in transition economies (Cai et al., 2017).

\section{CONCLUSIONS}

In this study, we set out to understand how cognitive framing of initiative failure affects further strategic decision-making by entrepreneurs and managers, in terms of exploitation and exploration. Our findings suggest that initiative failure increases explorative (decreases exploitative) choices of entrepreneurs to a larger degree than those of managers. We contribute to the literature in three ways. Firstly, we offer a nuanced perspective, by differentiating the notion of initiative failure from business/venture failure. We show that these two phenomena differ in terms of framing effects and how decision-makers react to them. Secondly, we test this psychological effect by empirically measuring changes in the intentions to pursue exploration and exploitation strategy, considering them as distinct but not mutually exclusive constructs. Thirdly, we provide the context of the transitional economy of Poland.

This study has practical implications for entrepreneurs, as it suggests that they should understand the role of initiative failure as an opportunity to learn and improve future actions. Moreover, our findings offer an important policy-making lesson, by emphasising the importance of support for entrepreneurs who face initiative failures. Moreover, public institutions should promulgate acceptance for entrepreneurial failure in society; not as a sign of weakness but that of strength and a vehicle of economic growth.

As all research, this study has limitations that point to directions for future research. Firstly, we should keep in mind that the decision-making considered in this study takes the form of intentions, which do not necessarily translate directly into actual behaviour (actions). For instance, managers who participated in our study were abstracted from their daily professional decision-making context. Therefore, we recommend that future research jointly analyse cognitions, intentions, and behaviours. Secondly, by taking into account only one condition (that of high uncertainty), our design sacrifices some external validity. The reflection of the situation in the real world depends upon the assumptions we applied. In the case of this study, we simplified reality by assuming that participants immediately know the results of their actions and make immediate decisions in response to this information. We distilled the 'pure' effect of failure for analytical purposes without taking into consideration a variety of additional factors; i.e. personal traits and external conditions that can potentially affect the ultimate decision outcome. We cannot claim the representativeness of the total 
population, which limits generalisation. Therefore, future (correlational) studies could consider a more complex design involving moderating variables. Specifically, exploring different types of entrepreneurial experience - in terms of quality and quantity - time spans, emotions, and individual characteristics as mediators or moderators would offer fruitful directions for further research. We believe that our assumptions provide a reliable test of our research question. We want to emphasise here that laboratory research allows for addressing theoretical questions (Davis et al., 2009) but requires caution in the application of its findings. In other words, laboratory research allows for testing a theory but is limited in terms of effects application (Calder et al., 1981). Despite these limitations, we believe that this study offers a contribution to the field of entrepreneurship.

\section{REFERENCES}

Ajzen, I. (1991). The theory of planned behaviour. Organizational Behaviour and Human Decision Processes, 50(2), 179-211.

Álamo-Vera, F.R., \& Suárez-Ortega, S.M. (2005). SMES' internationalization: firms and managerial factors. International Journal of Entrepreneurial Behaviour and Research, 11(4), 258-279.

Amankwah-Amoah, J., Boso, N., \& Antwi-Agyei, I. (2018). The effects of business failure experience on successive entrepreneurial engagements: An evolutionary phase model. Group and Organization Management, 43(4), 648-682.

Arend, R.J., Sarooghi, H., \& Burkemper, A. (2015). Effectuation as ineffectual? Applying the 3E theory-assesment framework to a proposed new theory of entrepreneurship. Academy of Management Review, 40(4), 630-651.

Brinckmann, J., Grichnik, D., \& Kapsa, D. (2010). Should entrepreneurs plan or just storm the castle? A meta-analysis on contextual factors impacting the business planning-performance relationship in small firms. Journal of Business Venturing, 25(1), 24-40.

Bruton, G.D., Ahlstrom, D., \& Obloj, K. (2008). Entrepreneurship in emerging economies: Where are we today and where should the research go in the future. Entrepreneurship Theory and Practice, 32(1), 1-14.

Cai, L., Guo, R., Fei, Y., \& Liu, Z. (2017). Effectuation, exploratory learning and new venture performance: evidence from China. Journal of Small Business Management, 55(3), 388-403.

Calder, B.J., Phillips, L.W., \& Tybout, A.M. (1981). Designing research for application. Journal of Consumer Research, 8(2), 197-207.

Ciszewska-Mlinaric, M., Obloj, K., \& Wasowska, A. (2016). Effectuation and causation: Two decisionmaking logics of INVs at the early stage of growth and internationalisation. Journal of East European Management Studies, 21(3), 275-297.

Cope, J. (2011). Entrepreneurial learning from failure: An interpretative phenomenological analysis. Journal of Business Venturing, 26(6), 604-623.

Covin, J.G., \& Miller, D. (2014). International entrepreneurial orientation: Conceptual considerations research themes, measurement issues, and future research directions. Entrepreneurship Theory and Practice, 38(1), 11-44.

Cyert, R., \& March, J. (1963). A Behavioural Theory of the Firm. Englewood Cliffs: Prentice Hall.

Czemiel-Grzybowska, W., \& Skowronek-Mielczarek, A. (2017). Entrepreneurship research in Poland. Technological and Economic Development of Economy, 23(3), 504-519. 
Dahlin, K.B., Chuang, Y.-T., \& Roulet, T.J. (2018). Opportunity, Motivation, and Ability to Learn from Failures and Errors: Review, Synthesis, and Ways to Move Forward. Academy of Management Annals, 12(1), 252-277.

Danneels, E., \& Vestal, A. (2020). Normalizing vs. analysing: Drawing the lessons from failure to enhance firm innovativeness. Journal of Business Venturing, 35(1), 105903.

Dew, N., Read, S., Sarasvathy, S.D., \& Wiltbank, R. (2008). Outlines of a behavioural theory of the entrepreneurial firm. A retrospective look at a behavioural theory of the firm. Journal of Economic Behaviour and Organization, 66(1), 37-59.

Espinoza-Benavides, J., \& Díaz, D. (2019). The entrepreneurial profile after failure. International Journal of Entrepreneurial Behaviour and Research, 25(8), 1634-1651.

Fang He, V., Sirén, C., Singh, S., Solomon, G., \& von Krogh, G. (2018). Keep Calm and Carry On: Emotion Regulation in Entrepreneurs' Learning from Failure. Entrepreneurship Theory and Practice, 42(4), 605-630.

Greve, H.R. (2003). A Behavioural Theory of R\&D Expenditures and Innovations: Evidence from Ship building. Academy of Management Journal, 46(6), 685-702.

Hauser, A., Eggers, F., \& Güldenberg, S. (2019). Strategic decision-making in SMEs: effectuation, causation, and the absence of strategy. Small Business Economics, 1-16.

He, Z.-L., \& Wong, P.-K. (2004). Exploration vs. Exploitation: An Empirical Test of the Ambidexterity Hypothesis. Organization Science, 15(4), 481-494.

Hitt, M.A., Ireland, R.D., Sirmon, D.G., \& Trahms, C.A. (2011). Strategic Entrepreneurship: Creating Value for Individuals, Organizations, and Society. Academy of Management Perspectives, 25(2), 57-75.

Hoskisson, R.E., \& Busenitz, L.W. (2002). Market uncertainty and learning distance in entrepreneurship entry mode choice. In M.A. Hitt, R.D. Ireland, S.M. Camp, \& D.L. Sexton (Eds.), Strategic entrepreneurship: Creating a new integrated mindset (pp. 151-172). Oxford, UK: Blackwell Publishers.

Hsu, D.K., Wiklund, J., \& Cotton, R.D. (2017a). Success, Failure, and Entrepreneurial Reentry: An Experimental Assessment of the Veracity of Self-Efficacy and Prospect Theory. Entrepreneurship Theory and Practice, 41(1), 19-47.

Hsu, D. K., Simmons, S.A., \& Wieland, A.M. (2017b). Designing entrepreneurship experiments: A review, typology, and research agenda. Organizational Research Methods, 20(3), 379-412.

Ireland, R.D., Hitt, M.A., \& Sirmon, D.G. (2003). A Model of Strategic Entrepreneurship: The Construct and its Dimensions. Journal of Management, 29(6), 963-989.

Kahneman, D., \& Tversky, A. (1979). Prospect Theory: An Analysis of Decision under Risk. Econometrica, 47(2), 263-291.

Kahneman, D., \& Tversky, A. (1982). Variants of uncertainty. Cognition, 11(2), 143-157.

Kauppinen, A., Paloniemi, K., \& Juho, A. (2019). Failed firm founders' grief coping during mentoring: Learning as the single catalyst of their restarting performance narratives. The International Journal of Management Education (in press), 100288.

Khelil, N. (2016). The many faces of entrepreneurial failure: Insights from an empirical taxonomy. Journal of Business Venturing, 31(1), 72-94.

Kirzner, I.M. (1973). Competition and Entrepreneurship. Chicago, IL: University of Chicago Press.

Lin, S., Yamakawa, Y., \& Li, J. (2019). Emergent learning and change in strategy: empirical study of Chinese serial entrepreneurs with failure experience. International Entrepreneurship and Management Journal, 15(3), 773-792.

Liñán, F., \& Chen, Y. (2009). Development and Cross-Cultural Application of a Specific Instrument to Measure Entrepreneurial Intentions. Entrepreneurship Theory and Practice, 33(3), 593-617. 
Maitlis, S. (2005). The Social Processes of Organizational Sensemaking. Academy of Management Journal, 48(1), 21-49.

March, J.G. (1991). Exploration and Exploitation in Organizational Learning. Organization Science, 2(1), 71-87.

March, J.G., \& Shapira, Z. (1987). Managerial Perspectives on Risk and Risk Taking. Management Science, 33(11), 1404-1418.

McCarthy, A.M., Schoorman, F.D., \& Cooper, A.C. (1993). Reinvestment decisions by entrepreneurs: Rational decision-making or escalation of commitment?. Journal of Business Venturing, 8(1), 9-24.

McGrath, R.G. (1999). Falling Forward: Real Options Reasoning and Entrepreneurial Failure. Academy of Management Review, 24(1), 13-30.

Meade, A.W., \& Craig, S.B. (2012). Identifying careless responses in survey data. Psychological Methods, 17(1), 437.

Ocasio, W. (1997). Towards an Attention-based View of the Firm. Strategic Management Journal, 18(S1), 187-206.

Read, S., Sarasvathy, S., Dew, N., \& Wiltbank, R. (2016). Effectual entrepreneurship. Taylor \& Francis.

Sarasvathy, S. (2001). Causation and effectuation: toward a theoretical shift from economic inevitability to entrepreneurial contingency. Academy of Management Review, 26(2), 243-263.

Schoemaker, P.J.H. (1990). Are Risk-Attitudes Related Across Domains and Response Modes?. Management Science, 36(12), 1451-1463.

Shepherd, D.A. (2003). Learning from Business Failure: Propositions of Grief Recovery for the SelfEmployed. Academy of Management Review, 28(2), 318-328.

Shepherd, D.A., \& Haynie, J.M. (2011). Venture failure, stigma, and impression management: A selfverification, self-determination view. Strategic Entrepreneurship Journal, 5(2), 178-197.

Shepherd, D.A., \& Cardon, M.S. (2009). Negative Emotional Reactions to Project Failure and the SelfCompassion to Learn from the Experience. Journal of Management Studies, 46(6), 923-949.

Shepherd, D.A., Wiklund, J., \& Haynie, J.M. (2009). Moving forward: Balancing the financial and emotional costs of business failure. Journal of Business Venturing, 24(2), 134-148.

Shepherd, D.A., Patzelt, H., \& Wolfe, M. (2011). Moving Forward from Project Failure: Negative Emotions, Affective Commitment, and Learning from the Experience. Academy of Management Journal, 54(6), 1229-1259.

Shepherd, D.A., Patzelt, H., Williams, T.A., \& Warnecke, D. (2014). How does project termination impact project team members? Rapid termination, 'creeping death', and learning from failure. Journal of Management Studies, 51(4), 513-546.

Shepherd, D.A., Williams, T.A., \& Patzelt, H. (2015). Thinking about entrepreneurial decision making: Review and research agenda. Journal of Management, 41(1), 11-46.

Simon, M., \& Shrader, R.C. (2012). Entrepreneurial actions and optimistic overconfidence: The role of motivated reasoning in new product introductions. Journal of Business Venturing, 27(3), 291-309.

Stewart, W.H., \& Roth, P.L. (2001). Risk propensity differences between entrepreneurs and managers: A meta-analytic review. Journal of Applied Psychology, 86(1), 145-153.

Tushman, M.L., \& O'Reilly, C.A. (1996). Ambidextrous Organizations: Managing Evolutionary and Revolutionary Change. California Management Review, 38(4), 8-29.

Ucbasaran, D., Shepherd, D.A., Lockett, A., \& Lyon, S.J. (2013). Life After Business Failure: The Process and Consequences of Business Failure for Entrepreneurs. Journal of Management, 39(1), 163-202. 
Vershinina, N., Barrett, R., \& McHardy, P. (2017). Logics and rationalisations underpinning entrepreneurial decision-making. Journal of Small Business and Enterprise Development, 24(1), 158-175.

Yamakawa, Y., Peng, M.W., \& Deeds, D.L. (2015). Rising From the Ashes: Cognitive Determinants of Venture Growth After Entrepreneurial Failure. Entrepreneurship Theory and Practice, 39(2), 209-236.

\section{Authors}

The contribution share of authors is equal and amounted to $50 \%$ each of them.

\section{Piotr Wójcik}

$\mathrm{PhD}$ in Strategy (Warsaw School of Economics). Assistant Professor at Kozminski University, Department of Strategy. His research interests include dynamic capabilities, decision-making, and international business.

Correspondence to: Dr Piotr Wójcik, Kozminski University, Jagiellońska 59, 03-301 Warszawa, Poland, e-mail: pwojcik@kozminski.edu.pl

ORCID $\odot$ http://orcid.org/0000-0003-2275-1318

\section{Mariola Ciszewska-Mlinarič}

PhD in Strategy (Kozminski University). Associate Professor at Kozminski University, Department of Strategy. Her research interests include the internationalisation strategy of emerging market firms, internationalisation process, and decision-making.

Correspondence to: Prof. ALK dr hab. Mariola Ciszewska-Mlinarič, Kozminski University, Jagiellońska 59, 03-301 Warszawa, Poland, e-mail: mariolac@kozminski.edu.pl

ORCID (1) http://orcid.org/0000-0001-6048-2644

\section{Acknowledgements and Financial Disclosure}

The article came into being within the project 758 financed by Kozminski University in 2017.

\section{Copyright and License}

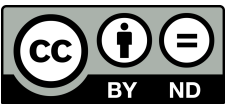

This article is published under the terms of the Creative Commons

Attribution - NoDerivs (CC BY-ND 4.0) License

http://creativecommons.org/licenses/by-nd/4.0/

Published by Cracow University of Economics - Krakow, Poland 
